\title{
The seven sustainability competences according to the RESFIA+D Model. Part B: practical experiences
}

\section{Niko ROORDA}

\section{Roorda Sustainability, The Netherlands \\ Anouchka RACHELSON \\ Miami Dade College, USA}

\begin{abstract}
:
Aim: In a previous article within this same journal, called "The Seven Sustainability Competences according to the RESFIA+D Model. Part A: Conceptual background", the origins, structure and validation were described of a model for professional competences for sustainable development, called RESFIA+D. The model provides an assessment and policy instrument that can easily be applied practically. Examples of such applications are offered in the current article. Companies, NGO's and other organizations may apply RESFIA+D as a structured tool for human resource development (HRD). Institutions for higher and vocational education can use the instrument for education (re)development, where curricula and didactic approaches are derived from a systematically designed competence profile in which sustainable development is integrated. Finally, individual professionals may use RESFIA+D as a tool for professional development.
\end{abstract}

Design / Research methods: The practical applications described in this article offered a way to evaluate and improve the RESFIA+D model, which contributed to the validation process of the assessment tool.

Conclusions / findings: Based on reactions of users, it is concluded that the RESFIA+D assessment is helpful to enable organizations and individual professionals to understand their strengths and weaknesses in their competences in relation to sustainable development; and to enable educational institutions, e.g. universities, to improve their educational goals, competence profiles and curricula related to sustainable development.

Originality, value of the article: The article focuses in a unique way on the roles of individual professionals towards sustainability, whereas most or all usual assessment models focus on the roles of either entire organizations, or of individual persons seen as civilians or customers.

Correspondence address: $\quad$ Niko Roorda, Roorda $\quad$ Sustainability, The Netherlands Email:nroorda@ planet.nl, Anouchka Rachelson, Miami Dade College, USA E-mail: arachels@ mdc.edu Received: 10.10.2018, Revised: 22.08.2019, Accepted: 22.08.2019

doi: http://dx.doi.org/10.29015/cerem. 854 
Keywords: competences, sustainable development, RESFIA+D, Human Resource Development (HRD), professionals, organizations, education

JEL: I20, I23, J24, Q01, Q15, Q56

\section{Introduction}

In a previous article by the authors of this article, called "The Seven Sustainability Competences according to the RESFIA+D Model. Part A: Conceptual background", the theoretical framework of RESFIA+D was explained. The current article continues, by offering examples of the application of RESFIA+D in real life.

$R E S F I A+D$ can be applied in three ways. For all three of them, the tool is used as an assessment instrument, paving the way to create development plans: for individual professionals (Section 2), for entire teams of an organization or department (Section 3), or for higher education (Section 4).

As an extra, Section 5 offers a simplified Self-Test that can directly be applied by the reader, followed by Section 6 in which a Pledge for professionals is proposed.

\section{Individual professionals: Personal Development Plan}

The first and easiest application is by an individual professional. It might be the reader, a colleague, a supervisor, a staff member, or an intern. Students can do it, as a part of their study program in a university, a college, or a school.

The assessment can be done repeatedly, for instance every one, two or three years, as a part of a cyclic professional development process.

\section{Step 1: Your present competence, according to yourself}

First, you go through all six generic competences one by one; and for each of them, you go through the three achievements that are defined.

If, as a preparation, a set of disciplinary competences has been defined for your profession (e.g. by an expert group, by the organization you work for, or by you), you include those as well. 
For each of these 18 or more achievements, you sincerely ask yourself, after reading the detailed level descriptions: Do I really do this, or at least do I do things that are comparable with these descriptions? At which level do I do it?

Don't fool yourself by being too optimistic; why would you?

\section{Step 2: Feedback from others}

Next, you invite one or more persons who are familiar with you and your work and whom you trust to score the 18 or more topics with you in mind. If enough people do this, you get a $360^{\circ}$ feedback.

Of course, if you cannot or don't want to get this kind of feedback, you can leave Step 2 out.

\section{Step 3: Your ambition}

Then, you define your ambition for each of the topics. Before you do, you might select a certain period of time in which you want to realize this ambition: i.e. a target date. The result may look like Figure 1, which is an actual result, scored a few years ago by a Dutch professional working as a consultant.

\section{Step 4: Personal Development Plan}

After you complete the assessment, you use the results to think about how you can realize your ambition. This includes things like: setting priorities, selecting methods to improve your competence levels (e.g. reading a book, doing an internship, participating in a training course, playing a serious game, investigating internet pages, accept coaching), finding facilities to do this (e.g. time, money, equipment, teachers, permissions). 


\section{Figure 1. A RESFIA+D result of an individual professional}

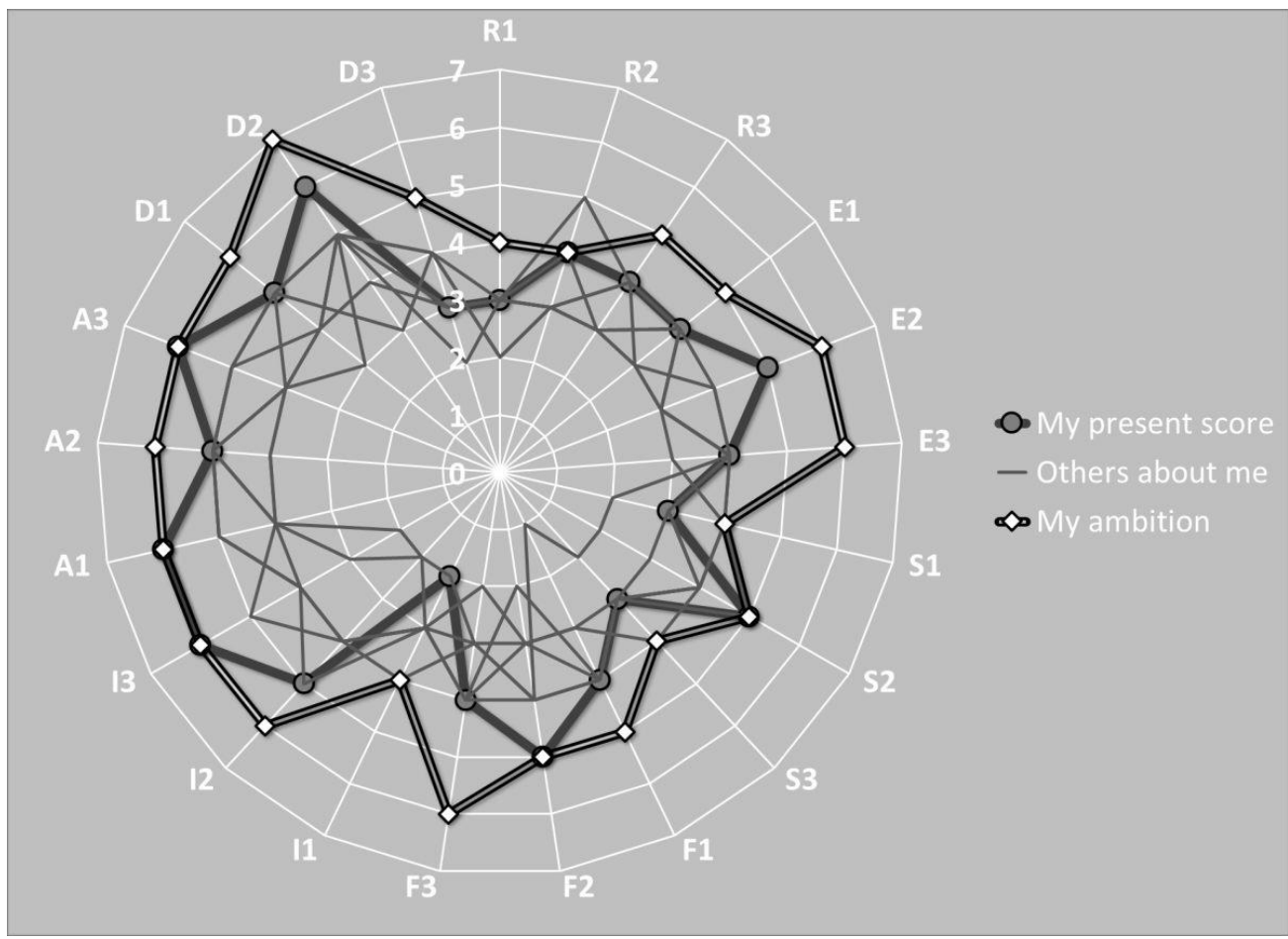

Source: Authors' own elaboration

\section{Organizations: Human Resource Development (HRD)}

If you work in a company, it may be decided that not only you but also others perform an individual RESFIA $+D$ assessment. Perhaps all the members of a certain team will participate: the consultants, the teachers, the doctors or nurses, the financial staff, the salespersons, and the top managers.

\section{Step 1: Minimum acceptable level}

As a preparation, a minimum requirement can be defined. This is a set of 18 (or more, if disciplinary competences were defined) levels that are the lowest acceptable level for anyone within the team. 


\section{Step 2: Ambition level}

At the other end, also an ambition level is defined for the entire team. This does not require every team member to meet the demands of this ambition; it involves the combined strength of the team as a whole. It may, for example, be decided that all ambition levels need to be possessed by at least one or two team members; if not, the team may not be able to perform its tasks properly.

\section{Step 3: Individual assessments}

All team members - or at least those who were selected for the assessment - do the assessment, as described in 8.1 . In this case, the $360^{\circ}$ feedback should definitely not be left out!

After the individual assessments are finished, the result may look like Figure 2.

\section{Figure 2. A RESFIA+D result of an organization}

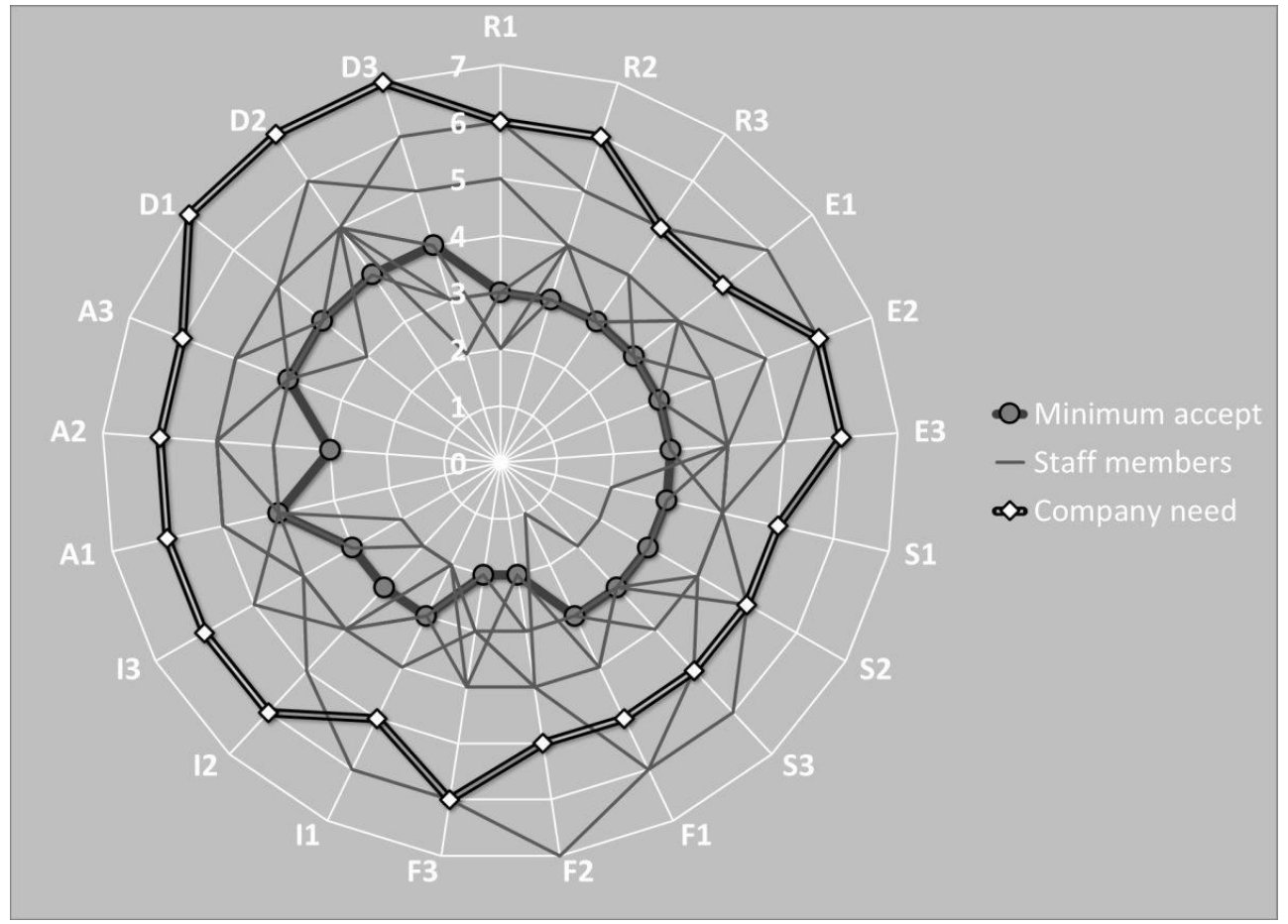




\section{Step 4: Staff Development Plan}

Based on this result, the team - or its managers - will develop a Staff Development Plan. This plan describes how the team is going to meet the formulated ambition within a limited period of time, e.g. a year. This may be based on negotiations with individual team members, resulting in agreements that certain members will follow courses, perhaps in-company, while others will find different ways to develop themselves. For those team members who don't meet the minimum demands, such a development plan is especially important; if it were to fail, it might ultimately lead to a dismissal procedure.

\section{Universities \& Colleges: Curriculum Development}

RESFIA $+D$ has also proved to be valuable for educational institutions, especially for study programs and their curricula. You can think of scientific and vocational education, in universities, colleges and schools.

The method has been used for a wide variety of disciplines, e.g. technological, economic, social, agricultural, healthcare, law and teacher education.

If a curriculum is to be (re)designed, this process should always start at the end, that is by (re)defining the outcomes of the study program, formulated as a set of competences of the graduates. This is where RESFIA+D comes in. When the competence profile is defined in a proper way, the curriculum contents as well as the curriculum structure and didactic methods can be derived from it.

\section{Step 1: Composing an assessment group}

As a preparation for the assessment, a group of circa ten to fifteen people is formed. Together, they have to be representative of all those who are stakeholders of the study program.

Another demand for each of the group members is that they are sufficiently familiar with the current curriculum or, if no curriculum exists yet, with the demands of the professional field and of society in general in relation to the study program. 
The group will consist of:

- lecturers, professors;

- learners, students;

- program managers, deans and/or even the institution board;

- recent alumni (with a fresh memory of the entire study program) - unless the program is brand new;

- and experienced representatives of the academic or professional field the study program aims at.

In some cases, also:

- representatives of society in general, e.g. community leaders;

- education financers;

- representatives of special interest groups, e.g. minorities or the environment.

\section{Step 2: Creating consensus on present state and ambition}

The group meets only once, for half a day or a few hours more. At the beginning, the assessor (someone who is highly experienced in applying RESFIA+D for this purpose) explains the goals and structure of the assessment method and the purpose of the meeting.

Next, the assessor goes through all 18 achievements of the "RESFIA" part, i.e. the generic competences, one by one. If disciplinary competences were defined beforehand, they are applied as well. For each of the 18 or more achievements, the assessor asks three questions, which the group discusses until consensus is reached. The questions are:

1. For this specific achievement, which is the competence level each student should at least have acquired when graduating? (the ambition).

2. Which is the level that is demanded in the present competence profile?

3. And which level is actually realized by each and every graduate at the very least?

In many cases, the answers to those three questions may be different. It is not uncommon that the group concludes that the ambition for a certain achievement should be, for example, Level 6; while the profile of the program demands perhaps Level 5, and the level that is actually realized, at least by some graduates, may be 
Level 4. The overall result may look like Figure 3, which was an actual result of the assessment of a study program (Bachelor of Commerce) in 2014.

\section{Figure 3. A RESFIA+D result of a university curriculum}

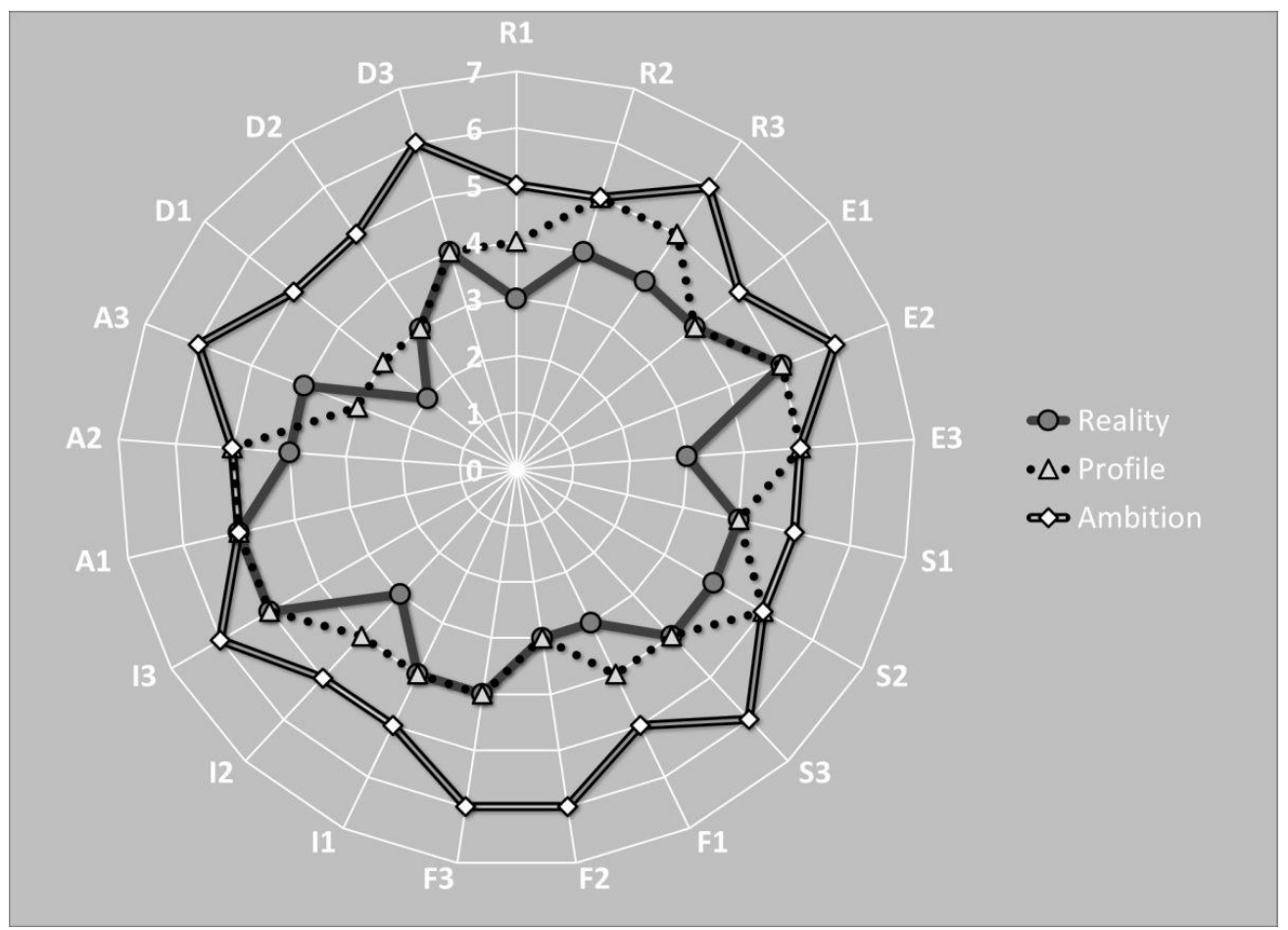

Source: Authors' own elaboration.

\section{Step 3: Selecting priorities}

After the group has reached consensus (majority voting should never be applied!) on the answers to the three questions for all 18 or more achievements, its task is nearly finished. What remains is setting priorities for an improvement project.

The strength of the assessment is that it is not some external expert who is going to tell the study program team that their program is not good enough. If there are differences between the ambitions and the present state - and there always are - it is the members of the group, including those who are responsible for the program, who draw the conclusions. They themselves determine the necessary improvements; they are the ones who give themselves a task. They own the conclusions. 
On the other hand, there may perhaps be as many as 15 or more improvements that are to be realized. But you probably know that any plan with more than - say three to five main goals is bound to fail. That is why it is important to select a limited set of highest priorities, out of all suggested improvements. Usually this appears to be an easy task. Each desired improvement has been discussed in detail. The group will probably know already, which of them are crucial first steps, and which others will follow easily as a result of the crucial first improvements. Selecting the priorities is usually done in ten minutes.

The result, which is to be turned into a report, formally has a status of recommendations to the management. Of course, the management is likely to accept and embrace these recommendations since they participated in the discussions, and the conclusions were drawn in consensus. It is a truly democratic process, creating a lot of support and enthusiasm.

\section{Step 4: Education Development Plan}

The final step will be for the management, i.e. for those people who carry the responsibility for the quality of the study program.

Preferably, the management team meets the very next day, when memories of the assessment are still fresh. During this meeting, the set of recommendations is turned into a solid Education Development Plan.

This plan arranges how and when the current competence profile will be adapted, followed by the necessary changes to the curriculum. The plan will involve a time schedule, a budget, the responsibilities of those who are going to do the actual work, their facilities, etc.

It will also contain an overview of the competences that the education team will need in order to be able to develop the improved program and to teach it. Consequently, a new staff development plan may be needed, if not all necessary competences are present within the team. If so, RESFIA $+D$ may again be useful, this time along the lines of Sections 2 and 3, above. 
After the plan is constructed, a period follows in which it is executed. At the end of this period, another round may follow in which $R E S F I A+D$ is applied again, leading to new conclusions, and so on. In this way, a quality circle of continuous improvement is closed.

\section{And now some action: The Self-Test}

While reading this article, you, the reader, may have become curious concerning your own current competence profile. And how about your ambitions: Would you perhaps aspire to reaching the master level of sustainability competence, at least for some of the competences?

\section{Personal growth toward sustainable mastership}

In the previous article, explaining the theoretical framework of RESFIA+D, seven levels of competence were described. They are:

Level 1: Apprentice

Level 2: Work under supervision

Level 3: Self-direct

Level 4: Integrate

Level 5: Improve

Level 6: Innovate

Level 7: Master

It stands to reason that nobody will ever attain absolute mastership in every aspect. Universal masters don't exist and have never done so. You can be a master in one area while being a fool or a novice in another. Life is a process of growth that doesn't end with official retirement. 


\section{The Self-Test}

The Self-Test is an easy way to apply $R E S F I A+D$ as an individual professional, as described in Section 2. In the form below (Table 1), you can insert your personal level for each of the RESFIA $+D$ competences. If you want to learn more about the background of the competences and how they relate to sustainable development and corporate social responsibility (CSR), you can read more about them in the university textbook Fundamentals of Sustainable Development $\left(2^{\text {nd }}\right.$ edition, Roorda 2017). In the form below, a column was added, referring to the appropriate sections in that book.

If you want, you can download the detailed level descriptions for each achievement, as explained in the previous article about the theoretical framework. If you don't want to do that, you can estimate the contents of the levels in a more intuitive way.

In Table 1, you can fill out three columns. In the first, you insert your personal scores, based on your own judgment and feelings. (Of course, you may insert very high scores everywhere if that makes you happy, but whom are you really fooling?)

In order to compare your personal judgment to the observations of others, you can ask one or more trusted persons to complete the second column. If you wish, you can even turn this into a parlor game by discussing all of your personal competences with a group of people and determine the scores together.

The right column represents your wish list. Select a concrete moment in the future that is meaningful to you, for instance, one, three, or ten years from now. What sort of professional do you want to be by then? What are your ambitions?

The bottom of the form is about $\boldsymbol{D}$, i.e. the disciplinary competences. You will find a number of empty boxes into which you can write the competences you consider relevant. Room has been reserved for six such competences, but you may limit or expand the list to any number you want. 


\section{Niko ROORDA, Anouchka RACHELSON}

\section{Table 1. The RESFIA+D Self-Test}

\begin{tabular}{|c|c|c|c|c|}
\hline $\begin{array}{l}\text { R: Responsibility } \\
\text { A sustainably competent } \\
\text { professional bears responsibility } \\
\text { for his or her own work. }\end{array}$ & $\begin{array}{l}\text { Explanation } \\
\text { (Fundamentals } \\
\text { of Sustainable } \\
\text { development) }\end{array}$ & $\begin{array}{l}\text { Your level } \\
\text { (According } \\
\text { to you) }\end{array}$ & $\begin{array}{l}\text { Your level } \\
\text { (According } \\
\text { to trusted } \\
\text { person) }\end{array}$ & $\begin{array}{l}\text { Your } \\
\text { ambition }\end{array}$ \\
\hline $\begin{array}{l}\text { R1. Create a stakeholder analysis } \\
\text { on the basis of the consequence } \\
\text { scope and the consequence } \\
\text { period }\end{array}$ & 5.5 & & & \\
\hline R2. Take personal responsibility & 8.2 & & & \\
\hline $\begin{array}{l}\text { R3. Be held personally } \\
\text { accountable with respect to } \\
\text { society (transparency) }\end{array}$ & 8.2 & & & \\
\hline $\begin{array}{l}\text { E: Emotional intelligence } \\
\text { A sustainably competent } \\
\text { professional empathizes with the } \\
\text { values and emotions of others. }\end{array}$ & $\begin{array}{l}\text { Explanation } \\
\text { Fundamentals } \\
\text { of Sustainable } \\
\text { development) }\end{array}$ & $\begin{array}{l}\text { Your level } \\
\text { (According } \\
\text { to you) }\end{array}$ & $\begin{array}{l}\text { Your level } \\
\text { (According } \\
\text { to trusted } \\
\text { person) }\end{array}$ & $\begin{array}{l}\text { Your } \\
\text { ambition }\end{array}$ \\
\hline $\begin{array}{l}\text { E1. Recognize and respect his or } \\
\text { her own values and those of } \\
\text { other people and cultures }\end{array}$ & 4.3 & & & \\
\hline $\begin{array}{l}\text { E2. Distinguish between facts, } \\
\text { assumptions and opinions }\end{array}$ & 8.5 & & & \\
\hline $\begin{array}{l}\text { E3. Cooperate on an } \\
\text { interdisciplinary and } \\
\text { transdisciplinary basis }\end{array}$ & $1.3,4.8$ & & & \\
\hline $\begin{array}{l}\text { S: System orientation } \\
\text { A sustainably competent } \\
\text { professional thinks and acts from a } \\
\text { systemic perspective. }\end{array}$ & $\begin{array}{l}\text { Explanation } \\
\text { (Fundamentals } \\
\text { of Sustainable } \\
\text { development) }\end{array}$ & $\begin{array}{l}\text { Your level } \\
\text { (According } \\
\text { to you) }\end{array}$ & $\begin{array}{l}\text { Your level } \\
\text { (According } \\
\text { to trusted } \\
\text { person) }\end{array}$ & $\begin{array}{l}\text { Your } \\
\text { ambition }\end{array}$ \\
\hline $\begin{array}{l}\text { S1. Think from systems: flexibly } \\
\text { zoom in and out on issues, i.e. } \\
\text { thinking analytically and } \\
\text { holistically in turn }\end{array}$ & 3.5 & & & \\
\hline $\begin{array}{l}\text { S2. Recognize flaws in the fabric } \\
\text { and sources of vigor in systems; } \\
\text { have the ability to use the } \\
\text { sources of vigor }\end{array}$ & Chapter 2 - 4 & & & \\
\hline $\begin{array}{l}\text { S3. Think integrally and chain } \\
\text { oriented }\end{array}$ & 8.3 & & & \\
\hline
\end{tabular}


Table 1. Cont....

\begin{tabular}{|c|c|c|c|c|}
\hline $\begin{array}{l}\text { F: Future orientation } \\
\text { A sustainably competent } \\
\text { professional thinks and acts on the } \\
\text { basis of a perspective of the future. }\end{array}$ & $\begin{array}{l}\text { Explanation } \\
\text { (Fundamentals } \\
\text { of Sustainable } \\
\text { development) }\end{array}$ & $\begin{array}{l}\text { Your level } \\
\text { (According } \\
\text { to you) }\end{array}$ & $\begin{array}{l}\text { Your level } \\
\text { (According } \\
\text { to trusted } \\
\text { person) }\end{array}$ & $\begin{array}{l}\text { Your } \\
\text { ambition }\end{array}$ \\
\hline $\begin{array}{l}\text { F1. Think on different time scales } \\
\text { - flexibly zoom in and out on } \\
\text { short- and long-term } \\
\text { approaches }\end{array}$ & 5.5 & & & \\
\hline $\begin{array}{l}\text { F2. Recognize and utilize non- } \\
\text { linear processes }\end{array}$ & 7.3 & & & \\
\hline $\begin{array}{l}\text { F3. Think innovatively, creatively, } \\
\text { out of the box }\end{array}$ & 8.4 & & & \\
\hline $\begin{array}{l}\text { I: Involvement } \\
\text { A sustainably competent } \\
\text { professional has a personal } \\
\text { involvement in sustainable } \\
\text { development. }\end{array}$ & $\begin{array}{l}\text { Explanation } \\
\text { (Fundamentals } \\
\text { of Sustainable } \\
\text { development) }\end{array}$ & $\begin{array}{l}\text { Your level } \\
\text { (According } \\
\text { to you) }\end{array}$ & $\begin{array}{l}\text { Your level } \\
\text { (According } \\
\text { to trusted } \\
\text { person) }\end{array}$ & $\begin{array}{l}\text { Your } \\
\text { ambition }\end{array}$ \\
\hline $\begin{array}{l}\text { I1. Consistently involve } \\
\text { sustainable development in his } \\
\text { or her own work as a } \\
\text { professional (sustainable } \\
\text { attitude) }\end{array}$ & 4.7 & & & \\
\hline $\begin{array}{l}\text { I2. Passionately work towards } \\
\text { dreams and ideals }\end{array}$ & 4.2 & & & \\
\hline $\begin{array}{l}\text { I3. Employ his or her conscience } \\
\text { as the ultimate yardstick }\end{array}$ & 8.2 & & & \\
\hline $\begin{array}{l}\text { A: Action skills } \\
\text { A sustainably competent } \\
\text { professional is decisive and } \\
\text { capable of acting. }\end{array}$ & $\begin{array}{l}\text { Explanation } \\
\text { (Fundamentals } \\
\text { of Sustainable } \\
\text { development) }\end{array}$ & $\begin{array}{l}\text { Your level } \\
\text { (According } \\
\text { to you) }\end{array}$ & $\begin{array}{l}\text { Your level } \\
\text { (According } \\
\text { to trusted } \\
\text { person) }\end{array}$ & $\begin{array}{l}\text { Your } \\
\text { ambition }\end{array}$ \\
\hline $\begin{array}{l}\text { A1. Weigh up the unweighable and } \\
\text { make decisions }\end{array}$ & 8.5 & & & \\
\hline A2. Deal with uncertainties & 6.3 & & & \\
\hline $\begin{array}{l}\text { A3. Act when the time is right, and } \\
\text { not go against the current: } \\
\text { "action without action" }\end{array}$ & 4.2 & & & \\
\hline
\end{tabular}


Niko ROORDA, Anouchka RACHELSON

Table 1. Cont. ...

\begin{tabular}{|l|l|l|l|}
\hline $\begin{array}{l}\text { D: Disciplinary competences } \\
\text { Add competences that are linked to your discipline } \\
\text { and/or profession. }\end{array}$ & $\begin{array}{l}\text { Your level } \\
\text { (According } \\
\text { to you) }\end{array}$ & $\begin{array}{l}\text { Your level } \\
\text { (According } \\
\text { to trusted } \\
\text { person) }\end{array}$ & $\begin{array}{l}\text { Your } \\
\text { ambition }\end{array}$ \\
\hline D1. & & & \\
\hline D2. & & & \\
\hline D3. & & & \\
\hline D4. & & & \\
\hline D5. & & & \\
\hline D6. & & & \\
\hline
\end{tabular}

Source: Authors' own elaboration.

You can insert your scores in the empty diagram of Figure 4, if you wish.

Figure 4. An empty RESFIA+D graph, to be used for the Self-Test

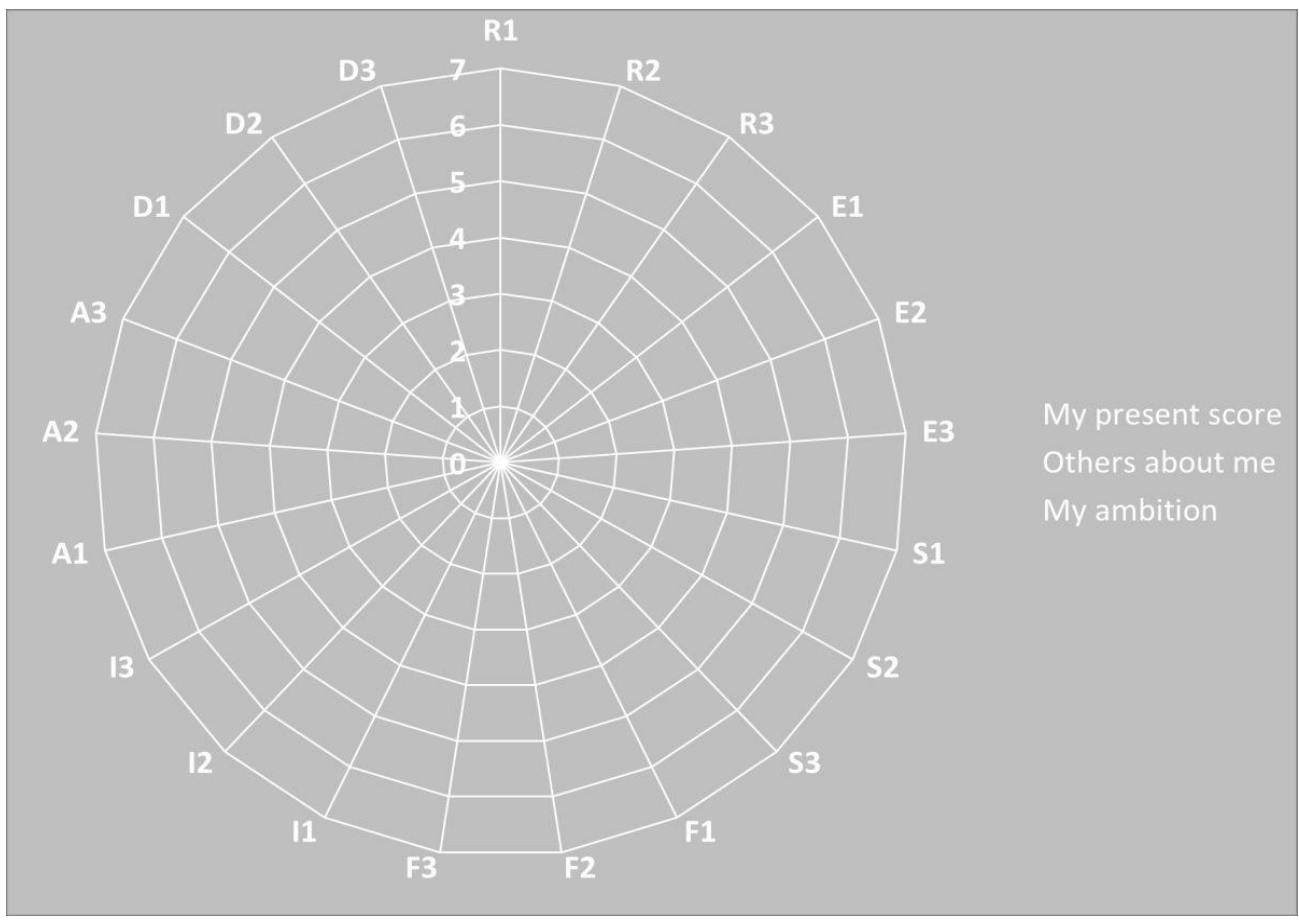

Source: Authors' own elaboration. 
If your ambitions exceed your present scores - hopefully they do, because: who does not want to improve? - then think of a plan to make your ambitions come true. Who knows? Maybe, within a couple of years you may have excellently mastered (certain aspects of) sustainable development. Anyway, you don't have to be a master to be able to act as a sustainably competent professional, as this article has shown.

\section{The Pledge}

Finally. Medical doctors have their Hippocratic Oath, which they pledge during their graduation ceremony at the end of their academic education program. This is with a good reason, since they are about to start their professional careers, during which, with some regularity, they - or at least some of them - will have the lives of their patients in their hands. Those are responsible professionals!

And others? Those of us who are not medical specialists? They, too, hold the lives of others in their hands, albeit in a more figurative sense: the lives of humans, of animals, or of nature in general. Managers may support or crush the careers of their employees. So may teachers in the course of the school lives or university programs of young individuals. Engineers design products in such a way that they may destroy or strengthen the natural environment. Caretakers make the lives of their clients bearable - or not. Artists represent the conscience of society - or they don't. Aren't those responsible professions too? They definitely are.

Hence the question: Do you have the courage to make a pledge? Promising you will behave as a responsible and sustainably competent professional? This section offers one. The Pledge is inspired inter alia by the Pugwash Declaration (Pugwash 1995), the INES Appeal to Engineers and Scientists (INES 1995), and of course by the Hippocratic Oath itself (KNMG 2003). More information about the Pledge is available online (Roorda, n.d.).

You can make your pledge to your husband or wife. To your children, your forefathers, your colleagues, The Bible, the Quran, the Bhagavad Gita, your stamp collection, or whatever is sacred to you. Legally binding it will not be. Morally binding it is. 
Here is the

\section{Pledge}

I promise that in my work I will consistently consider the consequences of my actions for society and for the environment, both today and in the future. I shall, before making decisions and whilst making them, conscientiously assess issues. I shall not undertake any actions geared towards harming people or the natural environment. I shall use my education, talents and experiences in order to make a contribution to a better world through sustainable development.

I accept that I am personally responsible for my choices and actions, and I promise that I will be held publicly accountable for my work by everyone for whom that work holds consequences. I shall not appeal to the fact that I acted on the instructions of others.

I promise that in my work I will not only make an effort for my own interests and my career, but also for my dreams and my ideals. In this I shall respect the values and the interests of others.

I understand that there will be times in the course of my career when it will be difficult to do what I am now promising to do. I will adhere to this pledge, even in those times.

\section{Concluding remarks}

RESFIA $+D$ has been applied in companies and various other organizations, where the model proved to be valuable as an HRD tool for the structured development related to sustainable development of staff members and entire teams.

It was also applied successfully to educational programs in various universities and colleges. There, it was a source for the development or improvement of the graduate profiles, expressed in the form of professional competences. Based on the results of the RESFIA $+D$ assessments, the educational teams were able next to integrate sustainable development systematically in the curriculum, both at the content level and the didactic methodologies. 
Besides, RESFIA $+D$ has been applied by individual professionals and students, who wished to acquire insight in their abilities to contribute through their work to sustainable development, aiming at a continuous improvement of those capabilities.

Feedback from the users of RESFIA $+D$ has made clear that the instrument was appreciated as an easily applicable and effective tool. No other assessment tools were known to the users that are comparable with $R E S F I A+D$, regarding both its focus on individual professionals and its applicability.

Using the principle of a "cover", derived from a comparison with various sets of colors, the RESFIA $+D$ model is in accordance with, and complements other models for SD (sustainable development) competences.

\section{References}

For references related to the theoretical framework of RESFIA $+D$, see the previous article by the authors of the current article: The Seven Sustainability Competences according to the RESFIA $+D$ Model. Part A: Conceptual background, published in this volume.

Other references:

INES (1995), INES appeal to engineers and scientists, International Network of Engineers and Scientists for Global Responsibility, International Network of Engineers and Scientists for Global Responsibility (INES), Berlin.

KNMG (2003), Hippocratic Oath, Koninklijke Nederlandsche Maatschappij tot bevordering der Geneeskunst (KNMG) \& Association of Universities in the Netherlands (VSNU), Utrecht.

Pugwash (1995), Pugwash Declaration, Student Pugwash USA, Washington DC.

Roorda N. (2017), Fundamentals of sustainable development, 2nd ed., Routledge, London - New York.

Roorda N. (n.d.), RESFIA+D: https://niko.roorda.nu/management-methods/resfia-d; FFEA: https://niko.roorda.nu/management-methods/ffea-assessment; The Pledge: https://niko.roorda.nu/pledge [14.09.2019]. 